\title{
塩素系防縮羊毛の強伸度におよぼす市販アルカリ洗剤の影響
}

\author{
豊金興業株式会社 岡部孝之 \\ 信州大学繊維学部 濱田州博 \\ 京都女子大学家政学部 曽我和世・中村 愛・岡田倫子・上甲恭平
}

\section{Effects of Domestic Alkaline Detergents on Strength and Elongation of Wool Fibers Shrink Proofed with Chlorine}

\author{
Takayuki Okabe $^{* 1}$, Kunihiro Hamada ${ }^{* 2}$, Kazuyo Soga ${ }^{* 3}$, Ai Nakamura $^{* 3}$, Michiko Okada $^{* 3}$, \\ and Kyohei Joko*3
}

\author{
${ }^{* 1}$ Tsuyakin Kogyo Co. Ltd., Konobunakashima, Ichinomiya Aichi 494-0007, Japan \\ ${ }^{* 2}$ Faculty of Textile Science and Technology, Shinshu University, Tokida, Ueda, Nagano 386-8567, Japan \\ ${ }^{* 3}$ Kyoto Women's University, Kita-hiyoshi, Imakumano, Higashiyama-ku, Kyoto 605-8501, Japan
}

\begin{abstract}
Kroy-treated wool and Dichlorocyanuric acid treated wool (DCCA-treated wool) were selected for wool fibers shrink proofed with chlorine. The laundering treatment with domestic alkaline detergents included any proteolytic enzyme decreased the strength and elongation at break of DCCA-treated wool with increasing of the laundering treatment time, but led to no significant changes for intact and Kroy-treated wool. From SEM images of fiber surface and cross section of each wool sample before and after the laundering treatment, it was found that cell membrane complex (CMC) regions in both cuticle and cortex phase of DCCA-treated wool fibers were damaged by the detergents. It was suggested that CMC structure of DCCA-treated wool fibers was deteriorated extremely, but that of Kroy-treated wool fibers was almost retained its original form as well as intact wool fibers. It was consider that DCCA-treated wool was decreased of the structural function of CMC to resist entering of enzyme and surfactant in cortex region, and it was became easy to receive any action of the detergent.
\end{abstract}

(Received 8 February, 2008 ; Accepted 20 May, 2008)

\section{1. 緒 言}

羊毛繊維製品の水系洗濯における収縮現象は，羊毛繊 維の特質であり，製品の品位を著しく落とすことになる， これを避けるために羊毛繊維製品は塩素系や石油系溶剤 による洗濯を行ってきた。しかし，近年，溶郕を用いる ことの環境及び人体への負荷, 家庭で洗濯できない, 水 性污れが除去されにくいといった課題が持ち上がり，水 系洗濯を可能とする防縮加工への要求が高まってきた [1].

羊毛繊維の防縮加工には, 既にいくつかの方法が提案 されている[2-5].この中でトップや系に対してはクロイ 加工，布に対してはDCCA 加工が多用されている[6].

防縮加工を施した羊毛繊維製品に対して消費者は，そ の製品取り扱い表示に準じて，家庭洗剤を用いた家庭洗 濯を行うことになる。現在の衣料用弱アルカリ洗剂には プロテアーゼ，七ルラーゼ，リパーゼ，アミラーゼなど の酵素が配合されている.これらの酵素は, 污れを分解. 除去し, 洗浄性を高める働きをしている. 中でもプロテ アーゼは, タンパク質の加水分解を促進させて污れを落
とすことから，洗剤の重要な補助剤である.

ところが，羊毛繊維はそれ自体がタンパク質であるた め，プロテアーゼなどの醳素の作用を受けて分解される [7-9]．そのため，羊毛繊維製品の家庭洗濯に用いる洗剤 には，酵素を含まない中性洗凨が推奖されている，中性 洗剂を使用した水系洗濯による形態変化打よび特性変化 に関する研究は既に行わ机ており，スケール除去により 防縮加工をした場合には，風合い，防しわ性，ドレープ 性，フィブリル化などに及ぼす洗濯による影響が小さい という結果が報告されている[10-12]. しかし, 洗浄性の 優れた弱アルカリ洗郕による洗濯の影響については，プ ロテアーゼが配合されていること，アルカリ性であるこ となどにより, 羊毛繊維が損傷されるとして詳細な研究 は行われていない。

我々は，弱アルカリ性の洗剤が使用できる耐酵素分解 性を有する羊毛繊維の開発をめざし研究を進めて打り [13]，午の基礎資料として，未加工羊毛打よび防縮加工 羊毛に対する洗剈成分の作用について検討を行っている. 本報では, 防縮加工羊毛としてクロイ加工羊毛, DCCA 
加工羊毛を選び，市販弱アルカリ性洗剤による洗濯後の 強度および伸度の変化を検討するとともに，洗剤成分の 作用機構について考察することを試みたので報告する.

\section{2. 実 験}

\section{1 羊毛試料}

メリノウール の未加工糸(日本毛織(株)，48 番双糸) と, 防縮加工糸としてメリノウール のクロイ加工糸(カネボウ 繊維(株), 48 番双糸, ハーコセット処理なし) および DCCA 加工糸(東亜紡織(株)，52 番双糸)をクロロホルム 8 時間の

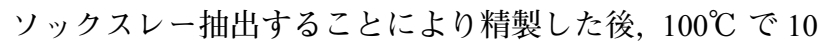
分間熱風乾燥して使用した。

\section{2 洗剤}

洗剤には，衣料用合成洗剤として市販の酵素入り弱ア ルカリ性洗剤 4 種類 $(\mathrm{A} \sim \mathrm{D})$ を用いた。 それぞれの洗剤に 含まれている成分については表 1 にまとめた.

\section{3 洗濯方法}

洗剂溶液は, 各洗剤に示されている標準濃度条件で $40^{\circ} \mathrm{C}$ の蒸留水に溶解させて調製した.

洗濯は，各洗剤に示されている標準浴比となるように 洗剂溶液中にカセ状の羊毛試料を入れ，インキュベーター を用いて $40^{\circ} \mathrm{C} て ゙ 60$ 分間振とう後，イオン交換水ですす ぎ脱水, $100^{\circ} \mathrm{C}$ で 10 分間熱風乾燥することで行った. こ の一連の処理を洗濯 A とし, 1 回から 5 回まで繰り返し て行った. また，同一条件で振とうせずに 24 時間漬け置 きすることでも行った. この処理を洗濯 S とし， 1 回から 10 回まで繰り返して行った。

\section{4 強伸度の測定}

JIS L 1095 の引張強さ測定方法に従い，定速緊張型試験 機を用いて羊毛試料 1 試料につき 20 本ずつ引張破断強度 および引張破断伸度を測定し，その平均值を強度および 伸度の值とした。

洗濯未処理状態での強度および伸度に対する処理後の 強度扎よび伸度の割合を，それぞれ強度保持率および伸 度保持率とした。

Table 1 Composition of domestic alkaline detergents used for this experiment. a : anion, $\mathrm{n}$ : nonion, + : presence, - : absence.

\begin{tabular}{lcccc}
\hline $\begin{array}{l}\text { Detergent } \\
\text { name }\end{array}$ & A & B & C & D \\
\hline $\begin{array}{l}\text { Surfactant } \\
\text { ionicity }\end{array}$ & $\mathrm{a} / \mathrm{n}$ & $\mathrm{a} / \mathrm{n}$ & $\mathrm{a}$ & $\mathrm{a}$ \\
\hline $\begin{array}{l}\text { Enzyme } \\
\text { (Protease) }\end{array}$ & + & + & + & + \\
\hline $\begin{array}{l}\text { Bleaching } \\
\text { agent }\end{array}$ & - & - & + & - \\
\hline $\begin{array}{l}\text { Fluorescent } \\
\text { whitening } \\
\text { agent }\end{array}$ & + & + & + & + \\
\hline
\end{tabular}

\section{5 走査型電子顕微鏡 (SEM) 観察}

羊毛試料の表面および引っ張り破断面の形状を走査型 電子顕微鏡 SM-520 (日本電子(株)) を用い, 常法に従い試料 を金蒸着し，加速電圧 $10 \mathrm{kV}$ で観察した。

\section{6 アルカリ溶解度}

羊毛試料を $0.1 \mathrm{~N}$ の水酸化ナトリウム水溶液により $65^{\circ} \mathrm{C}$, 1 時間処理した時の重量減少率をアルカリ溶解度とした [14].

\section{3. 結果と考察}

\section{1 洗濯試験}

洗剤 $\mathrm{A} \sim \mathrm{D}$ を用いて洗濯 $\mathrm{S}$ を 1 回行ったときの未加工 羊毛, クロイ加工羊毛打よび DCCA 加工羊毛に対する強 度と伸度を測定し，その結果を罒 1 に示した。 なお，罒 中のブランクは，洗剤を使用しないで洗濯を行った場合 を示している.

強度および伸度のいずれにおいても，未加工羊毛およ びクロイ加工羊毛では, 洗剤の種類による差はほとんど 見られず，ブランクの場合とほぼ同等の值であった。 こ れに対して，DCCA加工羊毛では，洗剤の種類による明 確な差が見られ，洗㓱 $\mathrm{A}, \mathrm{B}$ および $\mathrm{C}$ の場合にブランク に比べて明らかに強度，伸度ともに大きく低下した．特 に，洗剤 $\mathrm{C}$ の場合には最も影響が大きく，伸度はブラン クに比べて半分程度にまで低下した.

次に, 洗剤 $\mathrm{C}$ を用いて洗濯 $\mathrm{A}$ および洗濯 $\mathrm{S}$ を繰り返し て行った時の影響について検討した. 未加工羊毛, クロ イ加工羊毛および DCCA 加工羊毛に対する強度と伸度を 測定し, その結果を強度および伸度保持率で罒 2 に示し た。

洗濯 A において，未加工羊毛およびクロイ加工羊毛の 場合の強度では洗濯回数による低下は見られず，伸度に おいては繰り返し 5 回で 80〜90\%の保持率を示した。そ れに比べて, DCCA 加工羊毛の場合には, 洗濯回数の増 加に伴って強度, 伸度ともに著しく低下し, 繰り返し 5
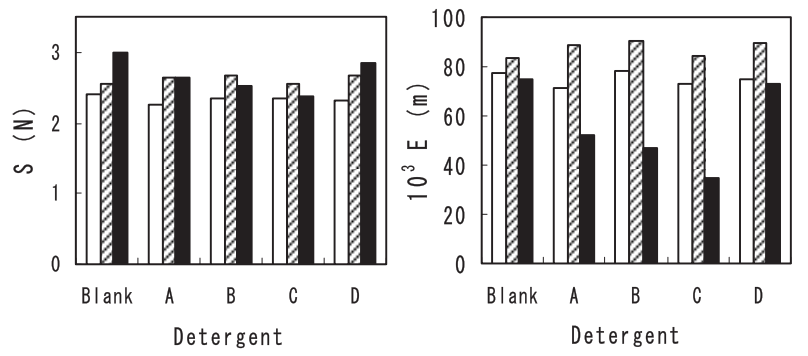

Fig. 1 Effects of laundering treatment used soaking method to 1 time with different detergents on the strength and elongation at break for wool samples. Blank means the absence of detergent. S : Strength at break, E: Elongation at break. $\square$ : Intact wool. $\mathbb{Z}$ : Kroy-treated wool. DCCA-treated wool. 

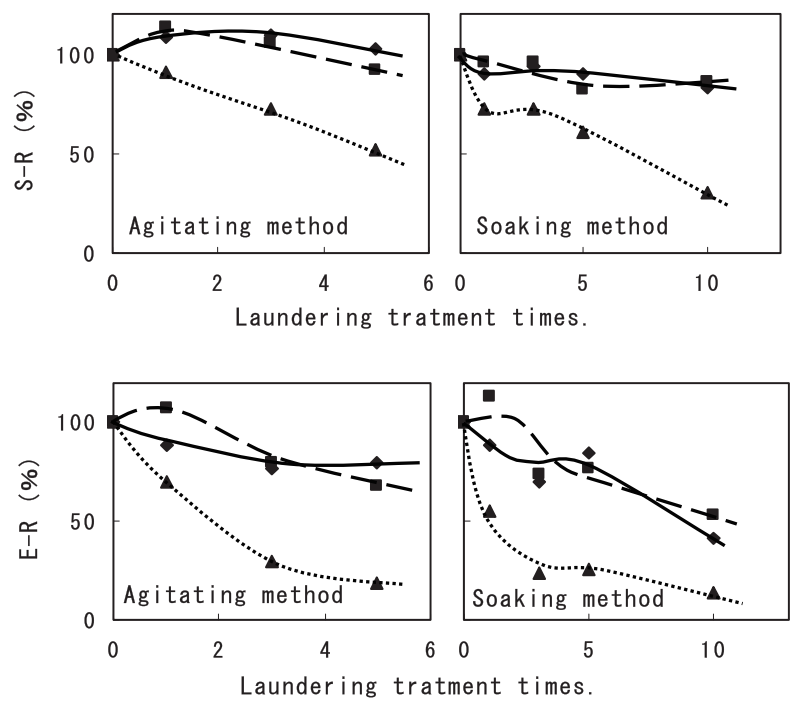

Fig. 2 Changes of the breaking strength and elongation retention of wool samples on laundering treatment times used agitating and soaking method with detergent C. S-R: Strength retention at break, E-R : Elongation retention at break.

$\checkmark$ : Intact wool. - $\rightarrow$ : Kroy-treated wool.

A...: DCCA-treated wool.

回で強度保持率は約 $50 \%$ に, 伸度保持率は約 $20 \%$ になっ た. 一方，洗濯 S の場合も洗濯 A と同様な変化が見られ たが，同じ洗濯回数における強度および伸度保持率の低 下は洗濯 S の方が大きく，特に DCCA 加工羊毛の伸度保 持率は繰り返し 5 回で約 30\%，10 回で 20\% 以下にまで低 下した.

以上の実験結果から, 弱アルカリ性洗剂を使用した洗 濯による羊毛繊維の強度および伸度の低下は，洗剤の種 類によって大きく異なり，本実験に用いた洗剤の中では, 洗剂 Cが最も強度および伸度を低下させた．また，羊毛 繊維の防縮加工の有無や防縮加工の種類によってもその 影響の受け方が異なり，本実験に用いた未加工羊毛，ク ロイ加工羊毛, DCCA 加工羊毛の 3 種類の羊毛試料の中 では, DCCA 加工羊毛がその影響を最も受けやすいこと が明らかになった。

さらに, 各試料の洗濯 $\mathrm{A}$ による強度および伸度の変化 が機械的衝撃を与えない洗濯 S の場合と同様であること から，本実験では，機械的衝撃による損傷はないか，あ るいは強度および伸度の変化に影響を与えない程度であ ると見なすことができた。

\section{2 洗剤成分の影響}

本実験に用いた洗剤の中で最も影響が顕著に表れた洗 剤 C を採りあげて，どの洗剤成分が羊毛試料の強度およ び伸度に影響をおよぼしているかを，DCCA加工羊毛を 用いた洗濯 A を繰り返し 5 回行うことにより検討した.

表 1 に示したように，洗剛 $\mathrm{C}$ には，酵素が含まれてい る.そこで，含有されている酵素の影響を調べるため, 洗剤 $\mathrm{C}$ の水溶液を煮沸して酵素を失活させた場合の強伸

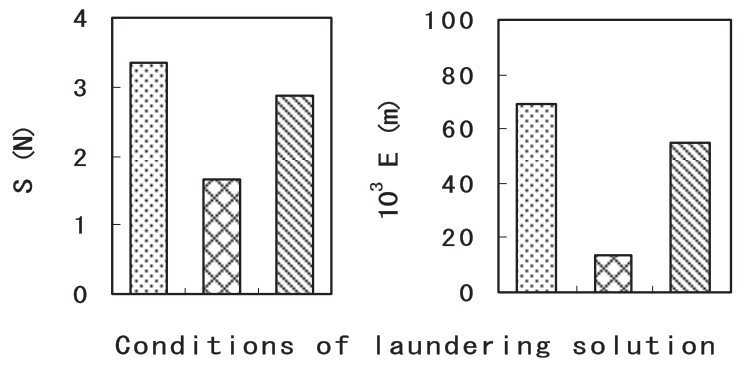

Fig. 3 The strength and elongation at break of DCCAtreated wool after five repeated laundering treatment used agitating method in the detergent $\mathrm{C}$ solution with and without boiling treatment. Blank means the absence of detergent. S : Strength at break, E : Elongation at break.

: Blank. $\square \times$ : Detergent $C$ solution without boiling treatment. $\mathrm{M}$ : Detergent $\mathrm{C}$ solution with boiling treatment.

度を煮沸しない場合の強伸度と比較した。その結果を困 3 に示す.

煮沸処理溶液での洗濯後の強度 - 伸度とも, 未者沸溶 液での洗濯後のそれらと比べ，明らかに高い值を示した。 しかし，ブランク処理の強伸度と比べて若干低い值であっ た.

この結果から, 洗剂中の酵素成分が羊毛繊維の強伸度 を著しく低下させることが確認できた．また，煮沸処理 をした場合でも，ブランクに比べると強度，伸度ともに 若干低下していることから, 酵素以外の洗㓮成分も強伸 度に若干影響していると考えられた。 したがって，洗剤 $\mathrm{C}$ での洗濯に伴う強伸度の低下は, 酵素と他の洗剂成分 との相乗作用によるものである.

\section{3 表面および破断面の変化}

次に，洗剂成分が羊毛試料にどのように作用している かの知見を得るために，SEMを用いての側面および破断 面の形態観察を行った. 洗劑 Cでの洗濯 A を繰り返し 5 回行った時の羊毛試料の表面形状の変化と破断面形態の 変化を図 4 に示す.

未加工羊毛打よびクロイ加工羊毛の表面形態は, 洗濯 前後でほとんど変化が見られない. 一方, DCCA 加工羊 毛では，洗濯前に確認できるスケールが洗濯後には多く が脱落して失われている．また，破断面形態においても， 未加工羊毛拉よびクロイ加工羊毛は, 洗濯前後でほとん ど変化が見られないのに対して, DCCA加工羊毛では, 洗濯前の垂直に切断した形態から洗濯後はコルテックス 細胞がフィブリル形状に大きく変化した纎維が観察でき, 洗剂成分が細胞膜複合体 (CMC) 域に作用して細胞間の接 着性を低下させていることがわかる.

これらの結果から, 洗濯 A の繰り返し 5 回では, 洗剤 成分は主に $\mathrm{CMC}$ 域に作用し，クチクル細胞間，クチクルコルテックス細胞間扎よびコルテックス細胞間の接着性 を低下させるように働くと考えられる. しかし，未加工 

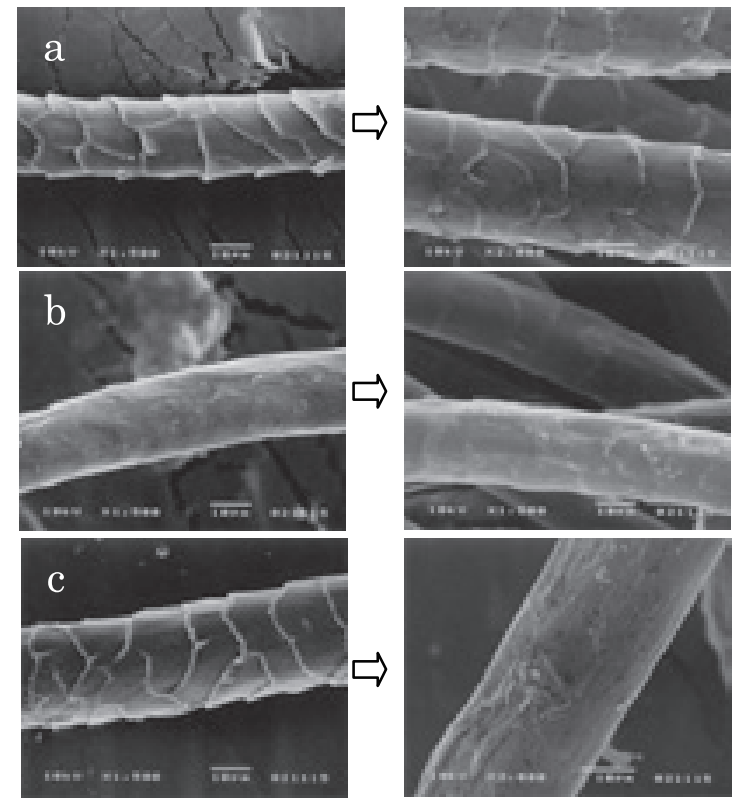

$<$ Surface morphology $>$
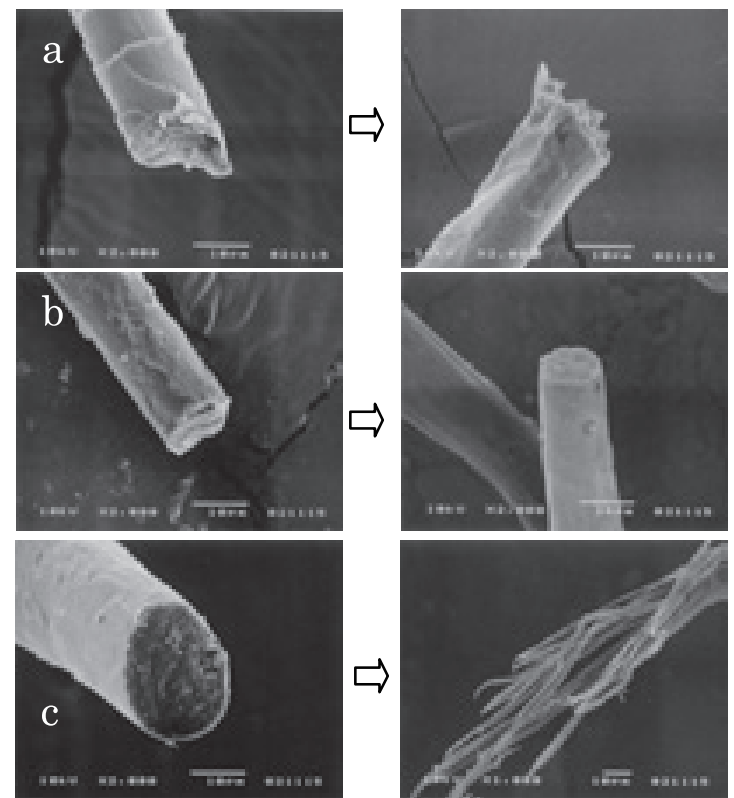

$<$ Cross section morphology at extending break $>$

Fig. 4 SEM images of fiber surface and cross section of each wool sample before and after the laundering treatment for 5 time used agitating method with detergent $\mathrm{C}$. $\mathrm{a}$ : Intact wool, $\mathrm{b}$ : Kroy-treated wool, c : DCCA-treated wool.

羊毛やクロイ加工羊毛では，見かけ上 CMCに作用してい ないように見える.

ここで，酵素を含め洗剤成分の作用機構を確認するた め, $\mathrm{CMC}$ の構造変化にともなう各羊毛試料の強伸度変化 について検討することとした。

\section{4 細胞膜複合体の構造変化の影響}

\subsection{1 溶剤抽出処理の影響}

有機溶媒は CMC の構成成分である非ケラチンタンパク や遊離脂質を抽出し， $\mathrm{CMC}$ の構造を乱す働きのあること
Table 2 Breaking strength and elongation of different modified wool samples treated by chloroform and 50\% $i$-propanol (IPA) aqueous solution.

\begin{tabular}{|c|c|c|}
\hline \multirow{2}{*}{ Wool Sample } & \multicolumn{2}{|c|}{ Chloroform treating } \\
\hline & Strength (N) & Elongation $\left(10^{-3} \mathrm{~m}\right)$ \\
\hline Intact wool & 2.78 & 82.7 \\
\hline Kroy-treated & 2.85 & 81.2 \\
\hline DCCA-treated & 3.18 & 71.7 \\
\hline \multirow{2}{*}{ Wool Sample } & \multicolumn{2}{|c|}{$50 \%$ IPA treating } \\
\hline & Strength (N) & Elongation $\left(10^{-3} \mathrm{~m}\right)$ \\
\hline Intact wool & 2.96 & 62.3 \\
\hline Kroy-treated & 2.73 & 49.4 \\
\hline DCCA-treated & 2.94 & 32.3 \\
\hline
\end{tabular}

はよく知られている $[15]$.

表 2 は $60^{\circ} \mathrm{C}$ の $50 \%$ イソプロパノール(IPA) 水溶液で 24 時間溶剤抽出 (IPA 处理)をして乾燥した各羊毛試料の強 度打よび伸度を, 前述のクロロホルム処理 ( $\mathrm{CH}$ 处理)のそ れらと比較して示したものである.

いずれの羊毛試料も, 強度に関しては IPA 処理後の值 が $\mathrm{CH}$ 処理後のそれとほとんど変わらないことがわかる. それに対し，伸度は各羊毛試料とも明らかに低くなって 打り, 特に防縮加工羊毛, その中でも DCCA 加工羊毛の 伸度が著しく低下している。

このことから，IPA 処理にともなう $\mathrm{CMC}$ の構造変化は CMC 成分の“すべり”を減少させるように働くが，すべり 後の細胞間接着強度にはほとんど影響していないと考え られる。また，防縮加工は，CMCの構造に対して IPAの 作用を受け易くさせて打り，并の程度は DCCA 加工の方 がクロイ加工に比べ幾分大きいものと推察される.

\section{4 .2 溶剤抽出後の洗濯試験}

次に, 表 2 に示した溶片処理試料に対して，洗剤 Cに よる洗濯 A を繰り返し 5 回まで行った時の強伸度変化を 測定した。矢の結果を四 5 に示した。罒にはブランク処 理の結果を併せて示した.

まず，未加工羊毛の場合，強度および伸度ともにブラ ンク処理と洗剤を用いた洗濯においてほぼ同じ傾向の変 化を示している。.すなわち, $\mathrm{CH}$ 処理では, 強度は洗㓮成 分の影響は見られず，繰り返し 5 回後までほとんど変化 していない，それに対して，伸度はブランク処理と洗剤 を用いた洗濯で全く同じ挙動を示したが，繰り返し 3 回 で若干低下する結果が得られた。一方，IPA 処理では, 強度及び伸度ともにブランク処理と洗剤を用いた洗濯で 全く変化が見られなかった。

このことは，まず， $\mathrm{CH}$ 処理した羊毛試料は，ブランク 処理によっても抽出される $\mathrm{CMC}$ 成分が存在し，その成分 が抽出されることによって若干伸度が低下することを示 している。 

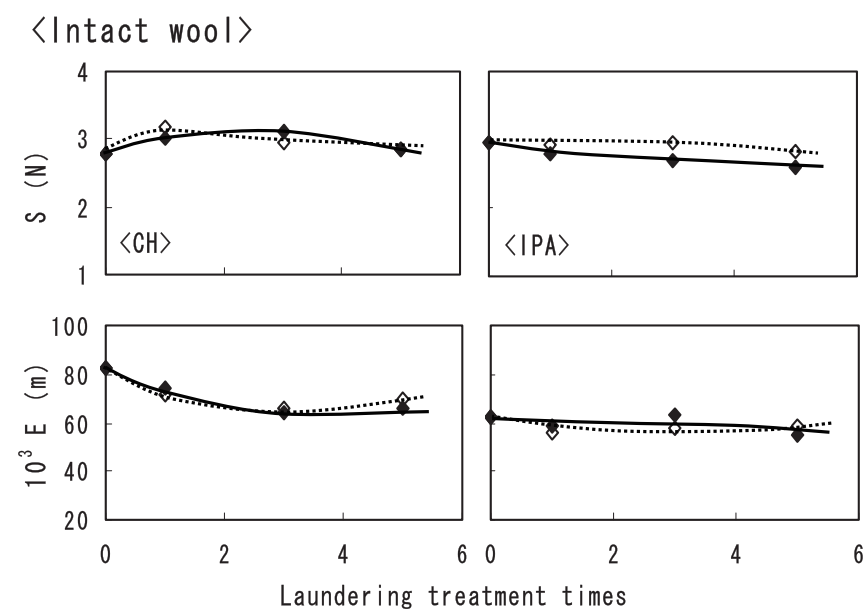

$\langle$ Kroy-treated wool $\rangle$
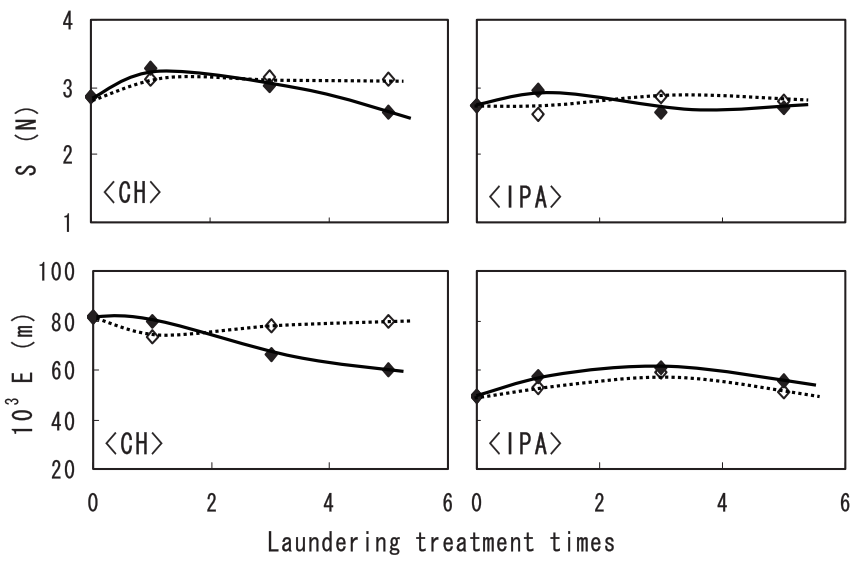

$\langle$ DCCA-treated wool $\rangle$
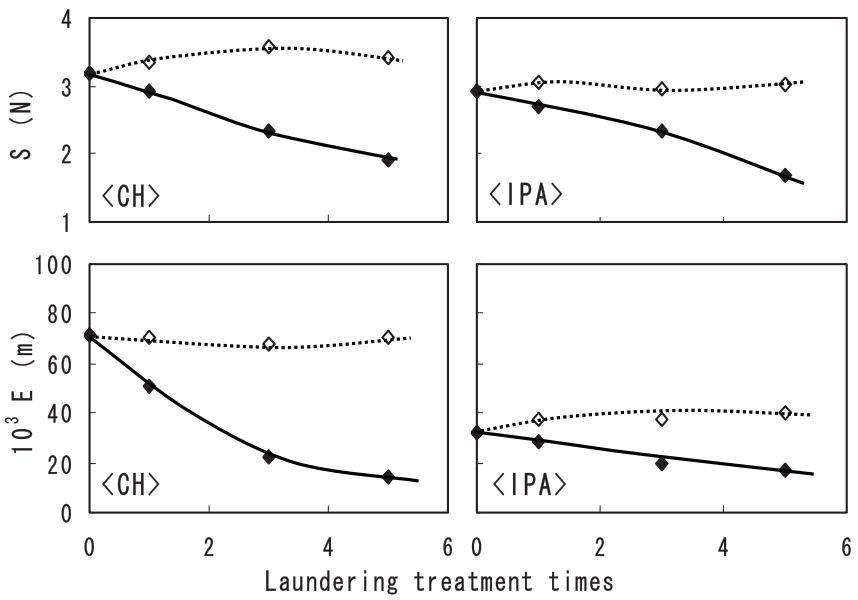

Fig. 5 Effects of detergent $\mathrm{C}$ and pretreatment with different solvents on the strength and elongation at break of wool samples to laundering treatment used agitating method for 5 times. S :

Strength at break, E : Elongation at break.

$\checkmark$ : Laundering treatment with detergent C. $\diamond$ : Blank (Laundering treatment without detergent). $<\mathrm{CH}>$ : Pretreatment with chloroform. $<$ IPA $>$ : Pretreatment with 50\% isopropanol solution.
また，羊毛繊維の本来の構造が保たれている未処理羊 毛の場合, IPA 処理によって変化した CMC 構造は, 洗剤 成分 (特に酵素) の作用に対する強度耐性を維持している ことを示している。言い換えれば，IPA処理ではブラン ク処理で抽出される成分は既に除去されているために, ブランク処理および洗剤を用いた洗濯によっても強度お よび伸度ともに変化がなかったものと考えられる。

一方, 防縮加工羊毛では, 溶剤处理によって CMC 構造 が変化した場合においても, クロイ加工と DCCA 加工で は前述した結果と同様に, 洗濯の作用に差異が認められ る. クロイ加工羊毛では, $\mathrm{CH}$ 処理において洗濯回数が増 加した場合に強度・伸度ともに若干低下するようである. それに対し，IPA 処理では，洗濯回数の影響は認められ ず，未処理試料と同様に CMC に作用していないと言える. ところが, DCCA 加工羊毛では, $\mathrm{CH}$ 処理, IPA 処理のい ずれにおいても洗濯回数の増加とともに強度・伸度は著 しく低下した。この結果は，IPA 処理による CMC の構造 変化にかかわらず, DCCA 加工で既に変化した CMC の構 造が，洗剤成分の作用に対する抵抗性を失っていること を示している.このことが, 繰り返し 5 回での強度およ び伸度の值が， $\mathrm{CH}$ 処理の場合と IPA 処理の場合とでほぼ 同一の值を示したものと考えられる.

以上の結果, IPA 処理した未加工羊毛と DCCA 加工羊 毛との洗濯耐性の差異から, IPA 処理による $\mathrm{CMC}$ 構造の 変化と DCCA 加工による $\mathrm{CMC}$ 構造の変化は, 化学的に は全く違う変化であることがわかる，この違いは，DCCA 加工での反応分子である塩素は細胞表面に存在する結合 脂質を分解することから [16]，この加工が CMC を構成す る脂質層, 特に結合脂質におよぼす作用の違いであると 考えられた.

\section{5 防縮加工羊毛間での相違点}

本実験での市販弱アルカリ洗剤による繰り返し洗濯で は，クロイ加工羊毛と DCCA 加工羊毛でも全く異なる損 傷挙動を示し，クロイ加工羊毛では洗剤に含まれる酵素 作用に耐性が有る結果となった，しかしながら，前報[13] で報告したように，ハーコセット処理をしていないクロ イ加工羊毛は，アルカリプロテアーゼであるサビナーゼ の $5 \%$ 水溶液 (温度 $60^{\circ} \mathrm{C}$ ) での処理により, 重量減少する とともに強度・伸度が著しく低下する，本実験で用いた クロイ加工羊毛も前報と同一試料であり酵素の作用を全 く受けない試料ではない.

一般に羊毛が染色加工などにより損傷を受けた場合， その損傷度の目安としてアルカリ溶解度が用いられる。 表 3 に今回用いた羊毛試料のアルカリ溶解度を示した。

Table 3 Alkali solubility (\%) of wool samples.

\begin{tabular}{cccc}
\hline & $\begin{array}{c}\text { Intact } \\
\text { wool }\end{array}$ & $\begin{array}{c}\text { Kroy- }^{-} \\
\text {treated wool }\end{array}$ & $\begin{array}{c}\text { DCCA- }^{-} \\
\text {treated wool }\end{array}$ \\
\hline $\begin{array}{c}\text { Alkali } \\
\text { solubility }\end{array}$ & $13.5 \%$ & $25.0 \%$ & $17.5 \%$ \\
\hline
\end{tabular}


この表から, クロイ加工羊毛のアルカリ溶解度が他の 試料のそれより高く，クロイ加工により損傷を受けてい ることがわかる.これらのことから，クロイ加工は酵素 作用を受けるにもかかわらず，洗濯では洗剤に含まれる 酵素の作用を受けていなことになる，この理由について は，次のように考えている。

洗剤に含まれる洗剤濃度は不明であるが，前報での酵 素処理溶液と比べてかなり濃度が低い. クロイ加工羊毛 の場合は，この酵素の大部分が表面層のクチクル成分(エ ンドクチクル)に吸着し， $\mathrm{CMC}$ へ浸透作用する酵素濃度 がかなり低くなると考えることができる，このことは， 図 4 に示したクロイ加工羊毛の表面形態写真において, 洗濯前のエンドクチクル表面が洗濯後はスムーズな表面 に変化していることからも支持される. それに対し, DCCA 加工羊毛では, クチクル細胞の表面脂質は損傷し親水化 しているが，クロイ加工羊毛のように酵素の大部分を吸 着するにいたらず，残存酵素が CMC 域に浸透し分解を引 き起こしていると考えられる.

すなわち, 防縮加工羊毛間での洗剤 Cでの洗濯による 影響度の違いは，洗剤に添加された酵素濃度が絶妙な濃 度であったことに起因すると考えることができる.

\section{4. 結 論}

家庭洗濯用として市販されている弱アルカリ性洗剤の 中には, 洗濯によって防縮加工羊毛の強度および伸度を 低下させるものがあり，その度合いは洗浏の種類によっ て異なった. また，防縮加工への洗剤による強度および 伸度への影響は, 防縮加工の種類によって異なり, 繰り 返し洗濯によってその差が明確となった。

本研究で防縮加工羊毛として用いたクロイ加工羊毛と DCCA 加工羊毛の結果を比較すると, DCCA 加工羊毛に 対する弱アルカリ性洗剤による影響の方が明らかに大き く, クロイ加工羊毛への影響は未加工羊毛とほとんど同 等であった. さらに, 洗剛によるこのような強伸度への 影響は, 主として洗剈中の酵素の作用によるものであっ た.

SEM 観察により洗濯後の各羊毛試料の形状変化を観察 した結果, 未加工羊毛およびクロイ加工羊毛は, 表面お よび破断面ともにほとんど変化していなかったが, DCCA 加工羊毛の場合には, クチクルの剥離とフィブリル化が
認められ, 繊維の表面及び内部の両方において分解が進 行していることが確認できた.

以上の結果から，羊毛繊維の各細胞を接着成分として 働く CMC が本来有している構造は, 洗郕成分の主剤であ る界面活性剂や添加剂である酵素の作用に対して強い抵 抗性を保有しているが，防縮加工での酸化作用によりこ の構造が崩れると, この抵抗性が低下し洗剤成分の作用 を容易に受け， $\mathrm{CMC}$ が持つすべり機能や接着機能が失わ れることで, 羊毛繊維の強度および伸度が低下したと考 えられた。

\section{文 献}

1. I. Hiroshi and E. Teramae, Dyeing and Finishing, 36, 215 (2001).

2. R. J. McPhee, Text. Res. J., 30, 358 (1960).

3. K. R. Makinson and J. A. Read, Proc. $5^{\text {th }}$ Int. Wool Text. Res. Conf., 3, 317 (1976).

4. M. Tahara, N. Mabuchi, and T. Takagishi, Sen'i Gakkaishi, 59(4), 153 (2003).

5. Y. Yoshimura, T. Ohe, and I. Abe, Textile Processing Technology, 36(11), 671 (2001).

6. M. Kaimori, Dyeing Industry, 32(12), 583 (1984).

7. M. Kitano, H. Kato, H. Ohno, and S. Yokoyama, Dyeing and Finishing, 43(3), 101 (1991).

8. Koizumi, Textile Processing Technology, 27, 234 (1992).

9. E. Heine and H. Hocker, Rev. Prog. Coloration, 25, 57 (1995).

10. M. Maezima, Kasei Gakkaishi, 45(9), 821 (1994).

11. K. Susukida, Mie Univ. kyoikugakubu Sizenkagaku Kenkyu Kiyo, 33, 95 (1982).

12. K. Arai, K. Inao, M. Oka, N. Yamashita, and K. Hukatsu, Kumamoto Pref. Univ. Seikatukagakubu Kiyo, 4, 21 (1998).

13. T. Okabe, K. Hamada, A. Shimizu, H. Matsumoto, and K. Joko, Sen'i Gakkaishi, 63(3), 60 (2007).

14. I.W.T.O., Specification of Test Method, IWTO, 4, 60 (E).

15. J. D. Leeder, D. B Bishop, and L. N. Jones, Text. Res. J., 53, 402 (1983).

16. A. P. Negri, H. J. Cornell, D. E. Rivett, Text. Res. J., 62(7), 381 (1992). 